\title{
Report on the Pilot Comprehensive Reform of Private Education: Based on the Survey of 62 Schools in X City
}

\author{
Ling $\mathrm{Li}^{*}$, Qian Zhao², Yu Wen ${ }^{3}$ \\ ${ }^{1}$ Institute of Education Policy of Faculty of Education, Southwest University, Chongqing, China \\ ${ }^{2}$ School of Foreign Languages, Chongqing College of Humanities, Science \& Technology, Chongqing, China \\ ${ }^{3}$ School of International Studies, Zhejiang University, Hangzhou, China \\ Email: "lingliswu@gmail.com
}

Received 16 November 2014; revised 18 December 2014; accepted 27 December 2014

Copyright @ 2015 by authors and Scientific Research Publishing Inc.

This work is licensed under the Creative Commons Attribution International License (CC BY).

http://creativecommons.org/licenses/by/4.0/

(c) (i) Open Access

\begin{abstract}
Private education is a major component of China's socialism education causes. The Chinese government pays high attention to private education and increase steady investment in it. This paper analyzes the reform and the development of private education in the dimensions of system design, actual effect and policy-making suggestions based on the research on the comprehensive reform of private education in $\mathrm{X}$ city.
\end{abstract}

\section{Keywords}

Private Education, Survey Research, Comprehensive Reform

\section{Introduction}

Private education is a major component of China's socialism education causes. During the process of China's private education development, four most representative regional development modes have emerged: education reserve in Guangdong [1], reform of public education system in Beijing [2], government-aided private education in Shanghai [3], and joint-stock schools in Wenzhou [4]. All these explorations and attempts in above regions have strongly driven the development of private education. This paper will analyze the reform and the development of private education in the dimensions of system design, actual effect and policy making suggestions based on the research on the comprehensive reform of private education in $\mathrm{X}$ city.

\footnotetext{
${ }^{*}$ Corresponding author.
}

How to cite this paper: Li, L., Zhao, Q. and Wen, Y. (2015) Report on the Pilot Comprehensive Reform of Private Education: Based on the Survey of 62 Schools in X City. Open Journal of Social Sciences, 3, 37-44. 


\section{Survey Design}

\subsection{Sampling Basis}

$\mathrm{X}$ city is home to a great number of large-scale private schools, which makes $\mathrm{X}$ city a more significant sample than other cities. The private education in $\mathrm{X}$ city started in an early stage, receives a rapid development, and makes great contribution. Now, there are 1748 private schools in X city, with 413,000 students on campus, which accounts for $27.3 \%$ of all the students on campus in X city. As a pilot city of the national private education reform, this survey will be of great importance to summarize the reform that is carried out in X city. In 2010, $\mathrm{X}$ city has been included as one of the pilot cities for the national private education reform, and since then, has issued a series of policies and measures. To summarize and analyze the private education reform in X city can offer precious lessons to the private education reform in other regions and also be needy in promoting the contemplation of the development of private education in a systematic approach.

\subsection{Purposes of the Survey}

This survey is to understand the effect of the pilot reform of private education in X city and offer cases for deepening the private education reform in other regions.

\subsection{Methodology}

Interview. Held forum for government officials who are in charge of the private education reform, presidents of schools and chairmen of broad who introduce the background of issuing the polices, the process of carrying out them and actual results of them to confirm the statistics from the questionnaire, see the major problems, explore the reasons for those problems and obtain related suggestions.

Questionnaire. Prepared in advance two types of questionnaires and allocated them to the Education Bureau of X city and all counties and the 62 pilot schools respectively in order to obtaining a general view of the situation of all districts, counties, sectors and schools that launch two-year pilot scheme.

Case study. The individual case of the survey, $\mathrm{X}$ school, is a typical private boarding school with high quality and large scale.

\subsection{Selection of Survey Subjects}

Selected survey subjects from different districts in X city, different educational levels(kindergartens, elementary schools and middle schools) and different position (government officials, broad of schools, schools presidents and teacher representatives) to conduct panel discussion.

\section{Reform Measures of X City}

In order to accelerate private Education Reform and Development, $\mathrm{X}$ city takes the following measures.

To strengthen the policy design for the comprehensive private education reform at the top level. Advice on the Implementation of Pilot National Overall Private Education and the Acceleration of Education Reform and Development [5] helps the government to form a one plus fourteen policy system in respect of registration management of legal person, financial support, financing policy, construction of human resources, property characterization, reasonable return, tax preferences, land policy, management of legal person and school-running system.

To set clear the approach of the comprehensive private education reform. The overall procedures of the comprehensive private education reform in X city are as follows: The rapid development of private education is the ultimate goal. Reconstruct the system in an all-round way and overcome the policy problems that private schools confront in teaching resources, property, tax and etc. The measures for this are to implement classified management, and formulate different policy system according to the profitable or non-profit characterization of private schools.

To classify private schools for management. On the principle of classified management, $\mathrm{X}$ city government classifies private schools into for-profit schools and nonprofit schools so that the government will offer different preferential policy packages in respect of financial support, construction of human resources, property right characterization, reasonable return, tax preference, land policy and financing policy. Nonprofit full-time private 
schools should be registered with the Civil Affairs Department as private legal persons, and for-profit full-time private schools enterprise legal persons.

To broaden support for private education development in an all-round way. Firstly, the city attracts social capital into the education field, allocates a group of public schools at non-compulsory stage to social organizations or individuals and intends to better construct schools by offering them low rent or free rent. Secondly, the city implements the system in which the charge of fee in private schools shall be filed. Private schools charge for fees according to their own rules, but the charge can only be put into use after it has been filed and publicized. Thirdly, in accordance with their different natures, private schools are granted different tax preference policies. Fourthly, a system is established in which government can purchase education services from private schools with subsidy for schools from the budget. Last, in terms of land use, private schools can obtain lands through appropriation and paid grant and enjoy deduction of construction fee.

To initiate innovative investment and financing system of private education. First of all, $\mathrm{X}$ government sets up an education development and investment group co., ltd. to improve the investment platform for education. Secondly, the government establishes an education bonding company led by government funds and joined with social capital to offer services like loan and guarantee to private schools. Thirdly, schools are allowed to apply for loans by using non-teaching facilities as collateral or the right of collecting tuition and intellectual property right as pledge. Fourthly, the government encourages private schools to establish an education fund with donated funds and school-running surplus in accordance with national regulations and privates schools registered as enterprise legal persons to explore new ways for establishing an education private equity investment fund. Last, the city formulates a loan policy especially for private schools with low interest to support the financing of private schools.

To set up a reasonable return system for private schools. As clearly stipulated in X city government's regulations, "The contributed assets belong to the contributors of private schools. The shares held by the contributors can be transferred, inherited, or given to another person, but the contributors cannot, in any case, defund investment when schools are in the period of existence.” Private schools that are registered as private legal persons can allocate proportionate bonus from the school-running surplus to the contributors as an award. Private schools that are registered as enterprise legal persons can gain profit as in enterprise system

To deepen the school operation system reform of private schools. The city attracts social capital into the education field so as to encourage fair, orderly competition between different investors and different schools. X city government establishes a modern school system, improve the legal person administration system of schools, further the construction of the boards and councils of private schools, safeguard the presidents' rights to manage schools according to law, and assure schools of their independent rights to operate schools.

To perfect the policy of the construction of teaching staff in private schools. Firstly, a personnel agency system is established, in which all the teachers in private schools are allowed to join personnel agency. Secondly, the city improves the social welfare system. Teachers in private schools should be included in the social welfare system with the standard of institutions and be able to enjoy the same amount of retirement fee as teachers in public schools do. Private schools that pay for the fees that should be submitted to all different departments in social welfare system will get financial aid from local ministry department, which takes the form of service purchase. Thirdly, related government departments should raise the salary standard and draw the lowest salary line for the teachers in private schools. Fourthly, the government should help promote the professional development of teachers in private schools, including them into the teacher training program; quotas of vocational assessment, teaching competitions and appraisal assessments for teachers in private schools should be separated from the ones for teachers in public schools. Last, it is necessary for the government to promote the reasonable flow of teachers between public schools and private schools. Teachers in public schools who support the teachings in private schools should retain their status as teachers in public schools, salary level and social welfare and enjoy the perks from private schools. Teachers in private schools who practice personnel agency and are included in the institutions' social welfare system can join the recruitment assessments in public schools. After the teacher is recruited officially, his/her working time and teaching time will be added to the previous ones he/she accumulated in private schools.

To form a pilot promotion system led by government. During the pilot promotion, $\mathrm{X}$ city has gradually established a governmental joint-meeting system of overall private education reform, supervision and notification system of overall private education reform by the municipal Party committee, supervision and inspection system 
especially for the private education reform and an annual assessment system.

Finally, complete content and organizational editing before formatting. Please take note of the following items when proofreading spelling and grammar:

\section{Development Status Quo}

\subsection{Distribution of Different Types of Private Schools in X City}

According to the survey, it is shown the distribution of different types of private schools in X city in Table 1 . What should be explained here is that there are 6 schools that contain both elementary and middle school sections in the same school, and 2 schools that have elementary, middle and high school sections in the same school.

\subsection{Distribution of Legal Person Nature of Private Schools}

Figure 1 shows the characterization of legal person of private schools in X city, of which most of schools in $\mathrm{X}$ city are nonprofit schools.

\subsection{Distribution of Students in Private Schools in X City}

Table 2 shows that the amount of students on campus has remained stable in private schools in X city in the recent four years.

\subsection{Social Security for Teachers in Private Schools in X City}

Teachers' social security in private schools in X city has been improved from 2010 to 2013, as shown in Table 3.

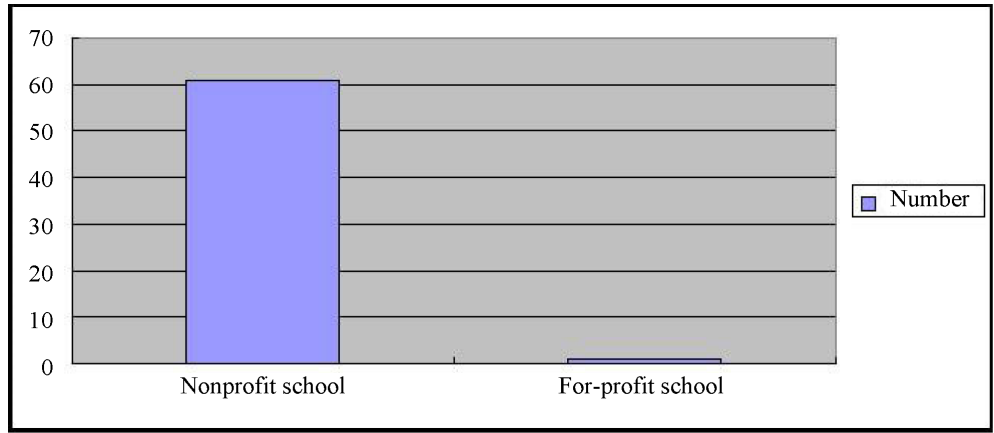

Figure 1. Distribution of characterization of legal person of private schools in X city.

Table 1. Distribution of different types of private schools in X city.

\begin{tabular}{cccccccc}
\hline School type & Kindergarten & Elementary school & Middle school & High school & University & Vocational school & Others \\
\hline Number & 37 & 9 & 9 & 13 & 0 & 3 \\
\hline
\end{tabular}

Table 2. Distribution of students in private schools in X city.

\begin{tabular}{cccc}
\hline Year & Students on campus & Enrolled students & Graduated students \\
2010 & 50,584 & 16,610 & 13,601 \\
2011 & 52,030 & 15,817 & 14,921 \\
2012 & 51,249 & 15,164 & 16,055 \\
2013 & 52,809 & 16,263 & 14,961 \\
\hline
\end{tabular}




\subsection{Flow of Teachers in Private Schools in X City}

Table 4 shows that the amount of teachers in private schools in X city has held steady in the recent four years. But the sum of new teachers is a little more than that of resigned teachers, which means that the position of being a teacher in private schools is unattractive.

\subsection{Financial Support to Private Schools in X City}

We can see from Table 5 that financial support to private schools has turned to steady-state growth annually from 2010 to 2013. It is shown that the local government attaches great importance to private education.

\subsection{Additional Investments to Private Schools by Schools' Sponsors}

As it is seen from Table 6, schools' sponsors have reduced additional investment in private schools annually, however, they increased additional investment in 2013.

\subsection{Tuition Standards of Private Schools in X City}

Table 7 shows that the tuition standards of kindergarten, elementary school, and middle school have remained stable in recently three years.

\subsection{School-Running Surplus of Nonprofit Private Schools in X City}

We can see from Table 8 that financial situation of nonprofit schools has got better from 2012 to 2013.

\section{Achievements, Problems, and Suggestions}

\subsection{Achievements}

After the reform started in $\mathrm{X}$ city, policies in such aspects as financial support, social security for teachers,

Table 3. Social security for teachers in private schools in X city.

\begin{tabular}{ccccc}
\hline Year & $\begin{array}{c}\text { Authorized teachers } \\
\text { (this region) }\end{array}$ & $\begin{array}{c}\text { Social security with public } \\
\text { institution's standard }\end{array}$ & $\begin{array}{c}\text { Social security with enterprise's } \\
\text { standard }\end{array}$ & No social security \\
\hline 2010 & 465 & 336 & 1814 & 644 \\
2013 & 553 & 1046 & 1783 & 294 \\
\hline
\end{tabular}

Table 4. Flow of teachers in private schools in X city.

\begin{tabular}{cccc}
\hline Year & Teachers in private schools & New teachers & Resigned teachers \\
2010 & 3082 & 422 & 326 \\
2011 & 3205 & 483 & 358 \\
2012 & 3270 & 401 & 396 \\
2013 & 3283 & 414 & 386 \\
\hline
\end{tabular}

Table 5. Financial support to private schools in X city (unit: RMB ten thousand).

\begin{tabular}{ccccc}
\hline Year & 2010 & 2011 & 2012 & 2013 \\
Amount & 600.7521 & 857.2955 & 2807.738 & 3814.2938 \\
\hline
\end{tabular}

Table 6. Additional investments in private schools by schools’ sponsors (unit: RMB ten thousand).

\begin{tabular}{ccccc}
\hline Year & 2010 & 2011 & 2012 & 2013 \\
\hline Amount of additional investment & 5849.5 & 4733.85 & 4100.33 \\
\hline
\end{tabular}


Table 7. Tuition standards of private schools in X city (unit: RMB).

\begin{tabular}{ccccccccc}
\hline Schools type & A & B & C & D & E & F & G & H \\
\hline Kindergarten & 1668.38 & 1820.68 & 2084.54 & 2239.81 & 303.78 & 338.62 & 339.90 & 352.41 \\
Elementary school & 7512.5 & 8875 & 10622.5 & 13600 & 13137.5 & 14637.5 & 11512.5 & 4275 \\
Middle school & 7512.5 & 9275 & 11000 & 13875 & 13137.5 & 9275 & 8800 & 962.5 \\
High school & 2648.18 & 2707.27 & 3343.64 & 4198.18 & 617.27 & 658.18 & 653.64 & 658.18 \\
\hline
\end{tabular}

Notes: A stands for the average tuition for each semester in 2010; B stands for the average sundry fees for each semester in 2010; C stands for the average tuition for each semester in 2011; D stands for the average sundry fees for each semester in 2011; E stands for the average tuition for each semester in 2012; F stands for the average sundry fees for each semester in 2012; G stands for the average tuition for each semester in 2013; H stands for the average sundry fees for each semester in 2013.

Table 8. Nonprofit schools with or without school-running surplus.

\begin{tabular}{ccc}
\hline Year & 2012 & 2013 \\
\hline Schools with school-running surplus & 2 & 19 \\
Schools without school-running surplus & 19 & 40 \\
Schools with deficit & 41 & 3 \\
\hline
\end{tabular}

charge of tuition and fees, and financing, have been successfully implemented in all the schools while the policies for tax preference, land property and property rights of legal person have been carried out in pilot schools. In 2013, there have been 415 pilot schools in X city. The amount of money for purchasing service and financial award for specific items was as high as RMB 380 million. 5565 teachers in private schools were engaged with personnel agency and 3166 teachers were included in the social security system for public institutions. The ice-breaking process starts in the carrying out of investment and financing policy. 2 schools have successfully received their loan of RMB 6 million and RMB 1 million respectively by using the right of charging tuition as pledge and education investment as mortgage. At the same time, we have attracted 4.5 billion social capitals into the education field. A new series of projects has been launched, including the Jiangsu Xiangyu Education Group, Shanghai New Epoch Education Group, Semir New Education School.

\subsection{Analysis of Existing Problems}

Although the private education in X city has made achievements, there are some problems:

A. Private schools' independent rights to recruitment and charge of fees are still greatly restricted.

B. Teachers in public schools and teachers in private schools are not equally treated. It is very common to see the teachers in private schools resign their jobs, which makes it difficult to maintain government's support for the continuity of social security for teachers.

C. Financial support standard is not scientific. Some schools did not receive the financial allowance from government.

D. The shortage of land limits the development of private schools.

E. Schools' property ownership is not clearly defined due to lack of defined provisions in related laws.

F. The proportion of public schools and private schools is unreasonable.

$\mathrm{G}$. The line between sponsors and managers is vague.

\subsection{Suggestions for Further Improvements}

\subsubsection{Alter the Proportion of Schools to Optimize Private Schools and Balance Gap between Public Schools}

The government should adhere to the principle of "Assure the foundation of public schools and optimize private schools” and reasonably plan pre-school education, foundation education and higher education in a scientific way and make adjustment to the proportion of public schools and private schools to meet the society's demand for education [6]. 


\subsubsection{Improve the Financial Support Policy and the Public Finance System}

The government should make adjustments to the financial allowance standard and change the amount of allowance according to the education quality and the financial balance of schools. The government should offer the land use rights to schools through administrative appropriation and other types of schools through grant. Private schools shall be given the same tax preference policy as that for public schools. The government should establish a pre-warning system for the financial support and estimate the upper and lower limit of government financial support according to the current financial balance and prediction of future financial development.

\subsubsection{Strengthen the Construction of Teaching Personnel and Explore Diversified School-Running Modes}

The government should set up a management and service center for teachers in private schools. The service center should be able to offer management service, including the qualification determination, flow of teachers, archive management and social security for teachers. Those eligible full-time teachers in private schools shall enjoy the same social insurances such as health care and pension insurances based on the standards for staff in public institutions, as teachers in public schools do. The government should better the system of teachers' flow between schools and establish a system for the orderly flow of teachers between public schools and private schools. It is of great importance to deepen the training of teachers in private schools and establish an introduction system of excellent teachers. The top-level teachers introduced to private schools will receive preferential policy in aspects of accommodation, their children's education and research fee.

\subsubsection{Assure the Independent Right of School-Running, and Standardize School Management}

The government should assure private schools of their independent rights of school operation and encourage private schools to run schools independently in terms of recruitment, teaching management, staff allocation and external cooperation and communication so as to reach the vision in which schools carry out teaching activities, the government administrates such activities and the society supervises such activities according to law. Related departments should set up an index system for the assessment of education quality of private schools to optimize the education quality. The index for private schools should be stipulated as the one of the education quality assessment in public schools at the same level with the own specialties and characters of private schools. It is important to clarify property right ownership, establish a financial supervision system and formulate regulations for the property transfer and clear ownership to clarify the rights, obligations and responsibilities of all types of private schools in asset ownership, use, profits and punishment. Besides, it is necessary to establish a comprehensive withdrawal mechanism for private schools.

\subsubsection{Promote the Reform of Investment and Financing Mechanism and Attract Social Capital into Education Field}

The property transfer system of private schools should be established to standardize the share capital transaction procedures at private schools. The government should reform the investment and financing mechanism and the investment and financing platform for education and help private schools to expand investment and financing channels by establishing education fund, investment of trust fund and stock market financing. To offer loan guarantee service requires the government to explore the way of setting up an education guarantee company led by governmental capital and joined with social capital.

\subsubsection{Practice Mixed Ownership and Innovate the School Operation System and Mechanism}

The government should accelerate the innovation on mechanism, strive to attract social capital to invest in education, and support all kinds of social strengths to practice social education whether through cooperation or shareholding system, in the form of solely foreign-owned enterprise or joint venture.

\section{Conclusion}

Combining its actual social and economic development, $\mathrm{X}$ city shows its unique regional characteristics in respect of the reform of school operation system, the optimization of investment and financing environment and financial support from government. It is believed that the reform of private education should adhere to the right direction of "optimizing private education and balancing public education". We should establish a joint mechanism designed by top level departments, led by government, coordinated between different departments and 
joined by societal strengths, take the realistic and market characteristics into serious account and utilize the market regulation and resource allocation mechanism to establish an education system where "schools' operation is mostly controlled by the government, the whole society participates in promoting education development while the mutual development of private education and public education is achieved."

\section{Acknowledgements}

This work was supported by the Key Program of National Social Science of China (Grant No. 13ASH005), the Project of Philosophy and Social Science Development Report of Ministry of Education of China (Grant No. 13JBGP040), and the Major Program of Science Research Plan of Faculty of Education at Southwest University (Grant No. 2013ZGXM05).

\section{References}

[1] Zhang, T.M. (2013) The Review of Creative Measures and Policies of Private Education Development in Guangdong (1979-2011). Guangdong Education, 12, 39-42.

[2] Wang, X. and Huang, Y.W. (2014) The New Horizon and Innovation Approach of the Development of Private Education. China Adult Education, 13, 22-25.

[3] Li, L. and Zhou, X.P. (2014) The Standard and Mode for the "Reasonable Return” of Private School. Journal of the Chinese Society of Education, 10, 50-53.

[4] Wang, X.Q. (2006) The Governing Structure and Mechanism of Joint-Stock School. Private Education Research, 1, 71-75.

[5] Center for National Education Development (2011) The Implementation of Pilot National Overall Private Education and the Acceleration of Education Reform and Development [Online Forum Comment]. http://www.moe.edu.cn/publicfiles/business/htmlfiles/moe/s6635/201207/139279.htm

[6] Mao, Y. (2009) The Equity Issues about the Competition between Public Colleges and Private Colleges in Education Market in China. Journal of Higher Education, 2, 1. 
Scientific Research Publishing (SCIRP) is one of the largest Open Access journal publishers. It is currently publishing more than 200 open access, online, peer-reviewed journals covering a wide range of academic disciplines. SCIRP serves the worldwide academic communities and contributes to the progress and application of science with its publication.

Other selected journals from SCIRP are listed as below. Submit your manuscript to us via either submit@scirp.org or Online Submission Portal.
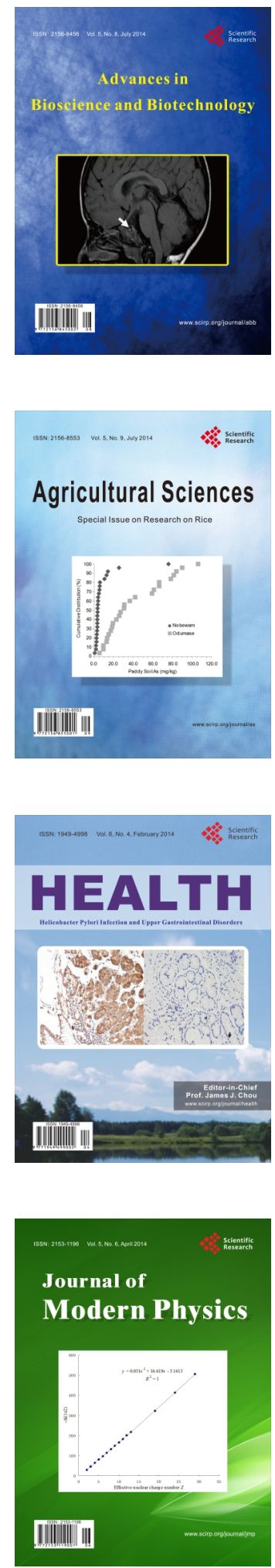
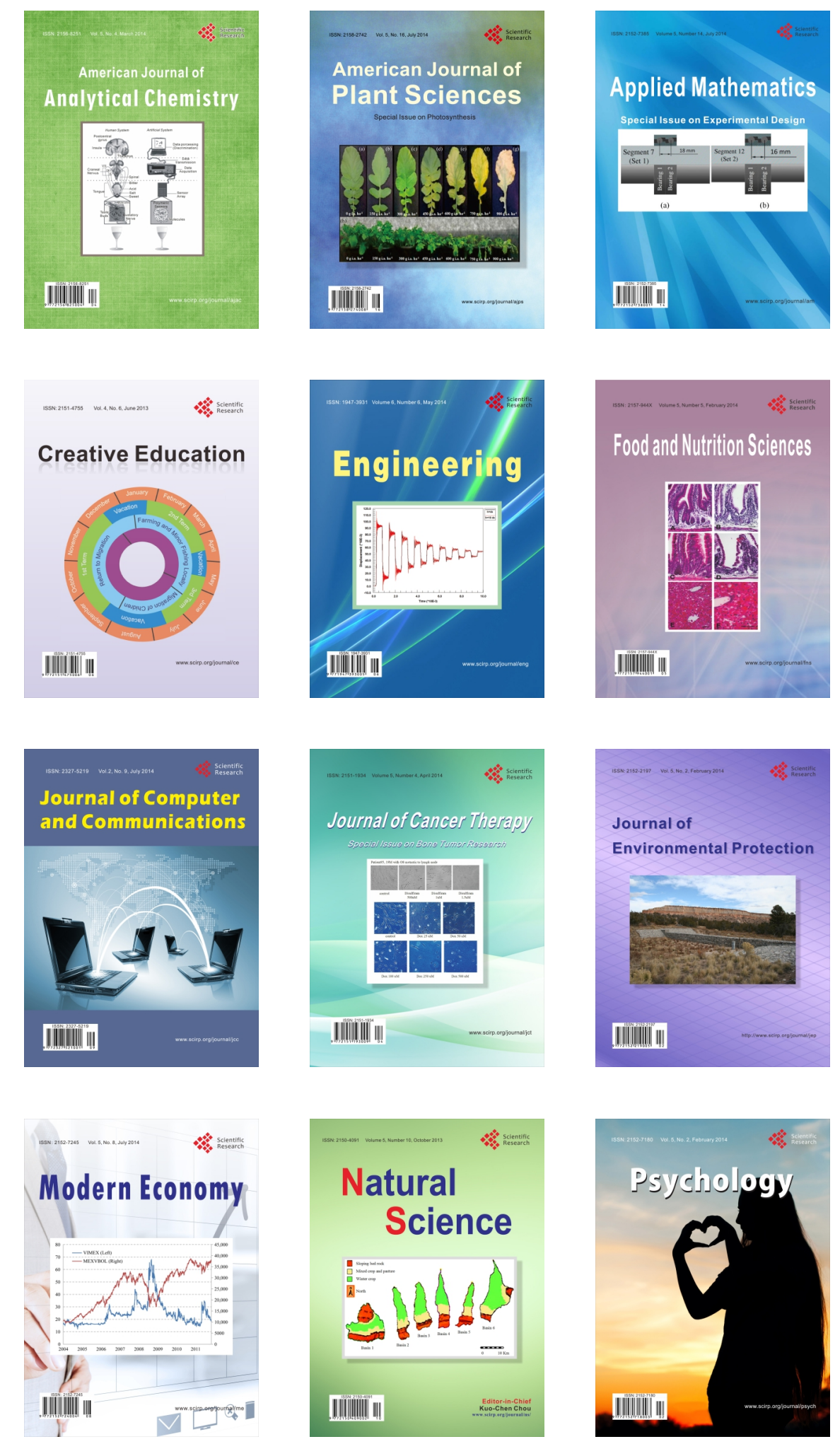